\title{
Familial long QT syndrome
}

INSERM

\section{Source}

INSERM. (1999). Orphanet: an online rare disease and orphan drug data base. Familial long QT syndrome. ORPHA:768

Cong enital long QT syndrome (LQTS) is a hereditary cardiac disease characterized by a prolong ation of the QT interval at basal ECG and by a high risk of life-threatening arrhythmias. 